\title{
Work and the Family with Children in Finland ${ }^{1}$
}

\author{
By LEENA SUOMINEN
}

The Finnish Population and

Family Welfare Federation

\section{Introduction}

Work plays an essential role in people's lives, and the conditions defining a family's life are decided to a great extent by the work the parents do. The immediate and secondary effects work has on the family are several: the family's material standard of living greatly depends on the amount the parents are paid for the work they do. The general feeling of security experienced by the members of the family is related to assurance that work will be available and that it will continue. The job's nature, hours of work, job environment and the time transportation to and from work takes affect workers in many ways, and in a family with children these effects are reflected in the children through the parents.

In the urbanized and industrialized society of today work is usually done outside the home, apart from the other members of the family. The differentiation of work so that it is done outside the home is only one phenomenon in the general sectorization of society, for going to school or to college, using various services and even partaking in leisure time activities, among other things, also take family members away from each other daily for several hours. These sectors have become »worlds unto themselves», which to a great extent exist independently of each other, because the working hours of parents of small children, for example, are not arranged according to the children's needs (SOU 1975 [1]). Another consequence of this differentiation is that children do not see their parents at work nor can they really get an idea of their parents' actual occupation, a very important area in their parents' lives.

One feature of work today is geographical mobility, which for families means, among other things, that in order to find work the parents may have

1 This article is based on the author's report entitled "The Family with Children in Finland», which in addition to the section "The family and work" includes "The structure of the family», "Family income», "The family as consumers" and "The family and housing». The report has been published in Finnish by the Finnish Population and Family Welfare Federation in the Kolmikanta-series, 1979: 7. 
to move from one town to another or even to another country. However, moving demands that people make many adjustments, and these demands are not always easily met.

The significance of phenomena related to work is even more pronounced today in the lives of families because all the more often both parents are employed outside the home.

\section{Economically active parents}

In Finland women have traditionally been a part of the labor force: for a long time women have made up $40 \%$ of the labor force. In the 1970 s the women's share of the labor force has continued to grow: in 1970 women formed $42 \%$ of the labor force, in $197245 \%$ and in $197847 \%$ (Niemi-Suominen 1976; CSO 1979 [1]). These figures are, of course, affected by the ratio of women to men in society in general.

The concept "labor force participation rate of women" is equal to the ratio of women in labor force to the total women of working age. In $197857 \%$ of all 15-74-year-old women belonged to the labor force; the highest labor force participation rate of women was in the age group 40-44 years: $84 \%$ belonged to the labor force in 1978 .

Changes in the rates of economically active married women in 1960, 1970 and 1975 are shown in Figure 1 by age group. In the Finnish censuses the term »economically active population» comprises all persons who, at the time of census, were 14 years of age or more and who did some work for pay or profit at least one half of the normal working hours (CSO 1978 [1]). The economically active population includes wage-earners, employers and, in addition, socalled family workers who work in an economic enterprise operated by a member of the same household for at least half of the normal working hours.

Figure 1 shows that in the 1970 s the rate of economically active married women has increased the most in the age group 35-44 years. A very strong increase has also appeared in the 30-34-year age group. In the 1960s the rate of economically active married women increased greatly in the age group $25-29$ years, while in the 1970 s the rate in this age group no longer grew as strongly. The economical activity rate of married women $35-39$ years did grow in the 1970 s by 11 percentage points (from $65 \%$ to $76 \%$ ).

It is more usual in Finland than in the other Nordic countries for married women to participate in the labor force. This was demonstrated also in an interview survey made in the Nordic countries on the welfare of the citizens by the Research Group for Comparative Sociology at University of Helsinki in 1972. At this time the rate of economically active married women in Finland was $63 \%$, in Sweden $61 \%$, in Denmark $54 \%$ and in Norway $31 \%$ (Kandolin 1978). 
F ig u re 1. Economically active married women by age in 1960, 1970 and 1975.

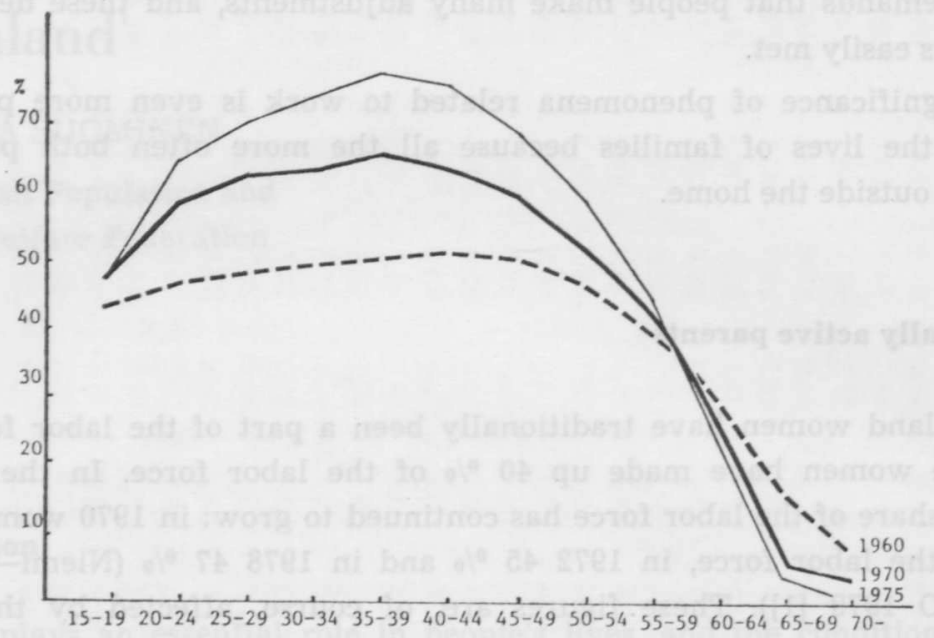

Source: Niemi-Suominen. 1976, CSO, $1978[1]$

Interesting is, of course, information concerning economical activity rate of persons with children. In Finland in the mid-1970s parents were economically active to quite a large extent: $69 \%$ of all mothers with children under 18 - including mothers in two-parent families and mothers in one-parent families - and $94 \%$ of all fathers were economically active. Among all mothers of children under school age $64 \%$ were economically active as were $97 \%$ of the fathers. Table 1 shows the economical activity rate of parents in different kinds of families according to the age of the children (Niemi-Suominen 1976; CSO $1978[1])$.

Table 1. Economically active parents in two-parent families and in oneparent families in 1970 and 1975.

Economically active parents in families with children under

Parent

7 years

children under 18 years

$\begin{array}{cccc}1970 & 1975 & 1970 & 1975 \\ \% & \% & \% & \%\end{array}$

Two-parent families

Husband

Wife

One-parent families

Single-parent mother

Single-parent father
82

94
57

67

80

94
80

88
81 88 
The economical activity rate of mothers in families with both parents has increased both absolutely and relatively from 1970 to 1975 . The relative rate of economically active mothers among all mothers has risen a total of ten percentage points: from $57 \%$ to $67 \%$. The economical activity rate of mothers with children under school age has not increased very much absolutely, but it has grown relatively by eight percentage points, so that over $60 \%$ of the mothers in two-parent families with children under school age are economically active in Finland.

It is rarely possible for single parents to choose between employment and full-time child care, and $82 \%$ of mothers in one-parent families with children under school age were working in 1975 , as were $94 \%$ of all fathers in oneparent families. The total number of economically active fathers in one-parent families has definitely increased from 1970 to 1975 , which, of course, is due to there being more fathers in one-parent families in the mid-1970s than at the beginning of the decade. The relative economical activity rate of these fathers has remained the same.

The relation of the number of children to economically active parents with children under school age is shown in Table 2 (CSO 1978 [1]).

$\mathrm{Tab}$ e 2. Economically active mothers in two-parent families and in oneparent families according to the number of children under age seven in 1970 and 1975.

Number of children under school age in the family

$\begin{array}{ccc}1 & 61 & 68 \\ 2 & 53 & 59 \\ 3 & 48 & 55 \\ 4+ & 45 & 50 \\ \text { Total } & 54 & 62\end{array}$

Economically active parents in percentages*

\begin{tabular}{|c|c|c|c|c|c|}
\hline \multicolumn{2}{|c|}{$\begin{array}{l}\text { Mothers in } \\
\text { two-parent } \\
\text { families }\end{array}$} & \multicolumn{2}{|c|}{$\begin{array}{c}\text { Mothers in } \\
\text { one-parent } \\
\text { families }\end{array}$} & \multicolumn{2}{|c|}{$\begin{array}{c}\text { Fathers in } \\
\text { one-parent } \\
\text { families }\end{array}$} \\
\hline 1970 & 1975 & 1970 & 1975 & 1970 & 1975 \\
\hline 61 & 68 & 84 & 84 & 93 & 93 \\
\hline 53 & 59 & 80 & 82 & 97 & 96 \\
\hline 48 & 55 & 75 & 75 & 96 & 93 \\
\hline 45 & 50 & 61 & 62 & 90 & 93 \\
\hline 54 & 62 & 80 & 82 & 94 & 94 \\
\hline
\end{tabular}

Table 2 e.g. shows that in Finland in $197568 \%$ of all mothers in twoparent families with one child under school age were economically active, while the corresponding figure of mothers in two-parent families with three children under school age was only $55 \%$. In two-parent families the activity

* The percentages show the proportion of families where either the mother or father was economically active out of all families of the type and size in question. 
rate of mothers with two children not yet of school age was clearly less than that of mothers with one child not yet of school age. The difference in percentage points between mothers with one child and with two children is greater than the activity differences between families with two children and three children and between families with three children and four or more.

The economical activity rate of mothers in one-parent families differs very little in families with one child and in families with two children. The largest drop occurs among mothers in one-parent families with four or more children as compared to those with three children.

In sum growth in economical activity rate from 1970 to 1975 among parents with children under school age in Finland has actually occured only among mothers in two-parent families; among one-parent families the rate was at about the same level in 1970 and 1975.

\section{The family and unemployment}

Unemployment has been a great problem in Finnish society in the late 1970s (cf. Figure 2) and unemployment apparently entails greater difficulties for families with children than for other groups in society. The significance of unemployment has been studied very little, but it is evident that unemployment is a bigger problem for a parent responsible for the care and support of one or more children than it is for one without responsibility.

The absence of work can mean depression reaction, a loss of self-confidence, a loss of initiative (Kivinen - Vadén 1978). These consequences of unemployment can hardly be considered favorable in view of rearing children. Because of unemployment the family's level of income is lowered, which means that the family must change its level of consumption. It may be difficult especially for children and young people to adjust to these changes in their material standard of living. The uncertainty of their economic existence means that the family cannot really make any plans for the future.

Information on the number of families with children who have had to face unemployment was made available in Labour Force Study 1978. In this study an "unemployed person» was defined as a person who was without work during the entire week of the study, who was available for work and who was seeking employment or waiting for an agreed job to begin or who was on forced leave from his job (CSO 1979 [2]).

In the autumn 1978 the rate of unemployment in Finland was $7.2 \%$ (CSO 1979 [1]). According to Labour Force Study 1978 there were 170000 unemployed persons in Finland, of whom 52000 had children under 18 and 30000 had children under seven. This means that under one third of the unemployed had children under 18, while over one half of the employed had children under 18. The difference is explained mainly by the age structure: very often the 
unemployed person was a young person. The families of the unemployed were also smaller than those of the employed: almost $60 \%$ of the unemployed who had children had only one child under 18 , while $45 \%$ of the employed had only one under-18-year-old child (CSO 1979 [2]).

Figure 2. Unemployed persons according to the Labour Force Survey (1), unemployed persons seeking jobs (2) and unfilled vacancies (3), (2) and (3) according to the Employment Service Statistics. Seasonally adjusted quarterly figures.

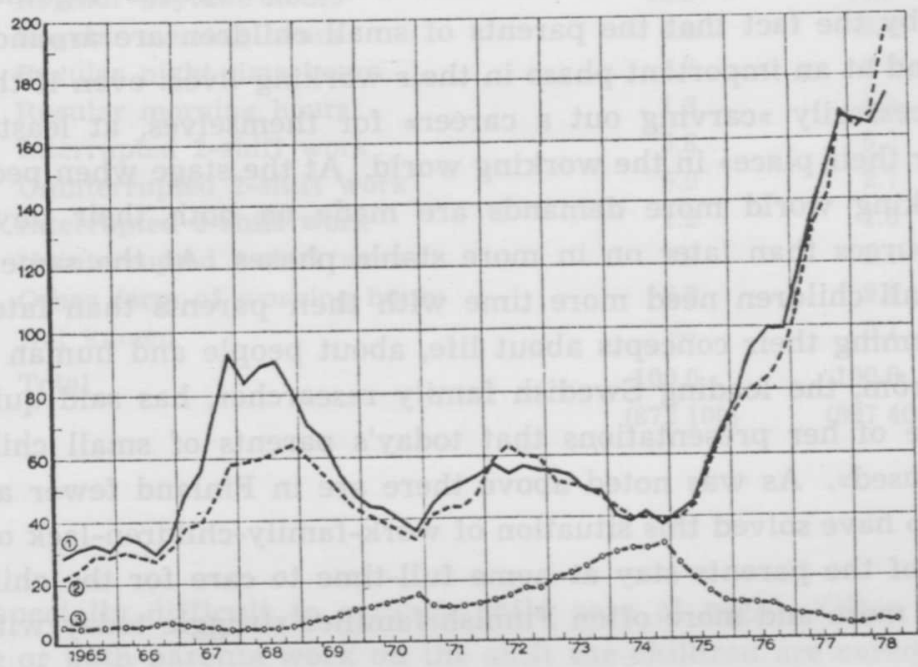

Source: Työvoimakatsaus 1978: 4

Very often the unemployed are young people at the stage in their lives when people begin to form families: examined by age group the largest number unemployed were in the 20-24-year-old group. Youth unemployment not only means difficulties for young people in finding a job and developing job skills, but also makes it more difficult for them to marry and plan having children. This means that unemployment should also be seen as a problem of "potential» families.

\section{The parents' working hours}

In today's industrialized and urbanized society few parents have the opportunity to combine their job and child care. The work the parents do quite forcefully limits the time available to spend with their children. The time parents use working must also include time spent going and coming from 
work and time spent taking the children to and from child care arrangements. It has been noted that although daily job hours have decreased, leisure time has really not increased. The reason for this is the vigorous diversification of society's activities especially in densely-settled areas: activities related to work, housing, services and leisure are all concentrated in their own areas, and these concentrated activities are situated far apart. A consequence of specialized activity locations - job concentrations, suburban housing areas - has not only been an impoverished environment but also that more and more people spend more and more time getting from one place to another (Syvänen 1976).

The amount and quality of the time a family spends together is also influenced by the fact that the parents of small children are around 20 to 35 years old and at an important phase in their working lives: even if the parents are not necessarily "carving out a career» for themselves, at least they are slooking for their place» in the working world. At the stage when people settle in the working world more demands are made on both their physical and mental resources than later on in more stable phases. At the same time the family's small children need more time with their parents than later on, for they are forming their concepts about life, about people and human relations. Rita Liljeström, the leading Swedish family researcher, has said quite to the point in one of her presentations that today's parents of small children are being »overused». As was noted above there are in Finland fewer and fewer families who have solved this situation of work-family-children-lack of time by having one of the parents stay at home full-time to care for the children. In other words more and more often Finnish families struggle today with a tight time budget.

Even if parents work regular daytime hours, they still have trouble fitting together the demands of work and family life. Work becomes an even greater problem for the family if one or both parents work irregular hours or on the shift. Regular hours do make it possible for family members to be together regularly and facilitate the arrangement of the family's various activities. Shift work decreases the time the family has to spend together and in many ways makes family activities more difficult.

According to the Working Conditions Survey $197716 \%$ of all Finnish wage earners, who then totaled 1.8 million, reported that they were working on the shift, and $73 \%$ of all wage earners were working regular daytime hours. Only $11 \%$ of administrative and clerical employees worked on the shift, but $19 \%$ of all laborers (CSO 1978 [2]). The following table shows wage earners, who form the majority of the employed labor force, by sex and type of working hours.

Among wage earners women worked regular daytime hours less frequently than men. The only type of shift work men did more than women was 3-shift work. Women worked evening hours and at uninterrupted 2-shift jobs definitely more often than men. 
Shift work not only has disadvantages related to one's physical health but also causes problems especially in family life and in child care. Parents working on the shift have to arrange child care at different times according to what week or day it is and possibly in different ways at different times.

Table 3. Wage earners by type of working hours and sex (autumn 1977).

$\begin{array}{lcc} & \text { Women } & \text { Men } \\ \text { Regular daytime hours } & 70.9 & 74.5 \\ \text { Regular evening hours } & 4.3 & 0.4 \\ \text { Regular night-time hours } & 0.7 & 0.5 \\ \text { Regular morning hours } & 1.3 & 0.5 \\ \text { Interrupted 2-shift work } & 5.8 & 5.2 \\ \text { Uninterrupted 2-shift work } & 5.0 & 2.7 \\ \text { Interrupted 3-shift work } & 1.2 & 1.6 \\ \text { Uninterrupted 3-shift work } & 3.9 & 5.1 \\ \text { Other form of working hours } & 6.9 & 9.4 \\ \text { Not known } & - & 0.1 \\ \text { Total } & 100.0 & 100.0 \\ & (872100) & (897400)\end{array}$

It is especially difficult to arrange child care at night. Often in families where one or both parents work on the shift the children are cared for by the parent who is at home or the parents try to arrange child care by seeing that their work shifts do not coincide. Single parents who work on the shift do not of course have an opportunity to take turns with anyone in child care, and for them arranging child care is especially problematic.

Shift work especially in view of a child's growth requirements has been studied by Anna-Raija Nummenmaa in Tampere (Nummenmaa 1978). The study examined the concrete consequences arising in a child's life when his parents have difficult working hours. The study was composed of 543 workers living in Tampere who had children under school age. A closer analysis was made of 151 randomly-chosen workers with difficult working hours. It was found in the study that especially little potential time to spend together remained in families where both parents had jobs on two- or three-shift-schedules or where one parent was constantly working evening or night-time hours (Nummenmaa 1978).

The parent's inconvenient working hours were reflected in basic child care routines, first in that the children's bedtimes were usually very late; late bedtimes were more common than usual in three-shift families, in one-parent families and in families where one parent worked continuously in the evenings or at night. Bedtimes varied also according to the parent's work schedule if 
they were working on shifts. Nevertheless, the simple matter of a regular bedtime is significant in increasing security as a basis for the child's mental and physical development (Nummenmaa 1978).

The parents' difficult working hours also mean that children must wake up early in the morning, go at an early hour to child care arrangements, come home late from child care and go through successive child care arrangements during one 24-hour period. Over one half of the families with difficult working hours had had continuous difficulties in arranging child care. At its worst this even meant that no child care person could be found and that the parents had been forced to leave the child by himself. When the parents' working shifts were timed badly, the child had been left alone in one out of four families. Leaving the child by himself had occurred in all age groups except among the under-one-year-olds, most frequently, however, in the overthree-year-old group. Even if the child was not left alone, successive child care arrangements meant disturbance and insecurity in the child's daily rhythm, especially when complicated arrangements were not always the same. Varying and successive child care arrangements were especially common in families where one parent had a three-shift job and the other a two-shift job or both parents had three-shift jobs (Nummenmaa 1978).

On the basis of the constant lack of care, the changes in 24-hour and daytime rhythm, the scarcity of interaction in families and the instability of the growth environment of children whose parents work difficult hours, the author of the Tampere shift work study came to the following conclusion: when parents have difficult job hours, this leads to such disadvantages in the child's daily life that action toward decreasing difficult working hours is the only way which in the long run could improve the children's life circumstances (Nummenmaa 1978). Decreasing or even ending shift work among the parents of small children is quite complicated, because the parents would then need to find a job with better working hours. It is not impossible, however, to arrange working hours that would take the needs of children more into consideration than the present ones do.

Part-time work is one way which has been brought up as a way to balance the demands made by the family and by the working world (SOU 1975 [2]). According to the Labour Force Study 1978 there were 158000 persons in Finland with a part-time job. This meant that at that time over $7 \%$ of all workers worked less than 30 hours a week at their main job during normal working hours. Four out of five part-time workers were women, and having a part-time job was markedly more common among women than men: $12 \%$ of employed women worked part-time, while the corresponding proportion of men was less than three per cent. Examined by work field part-time jobs were relatively most frequent in the various service industries. The most important reason for having a part-time job was care of the home and child care. Only about one fourth worked part-time because full-time jobs were not available (CSO 1979 [2]). 
Apparently people in Finland would like to work part-time somewhat more than they do, for when asked in Labour Force Study 1978, $13 \%$ of all fulltime workers wanted to work shorter hours. Women made up $67 \%$ of those wanting to work shorter hours; over one third (55 000) were mothers of children under seven years of age (CSO 1979 [2]).

\section{References}

CSO 1978 [1] Central Statistical Office of Finland. Population and Housing Census 1975. Volume III: Households and families. Official Statistics of Finland VI C: 105. Helsinki 1978.

CSO 1978 [2] Central Statistical Office of Finland. Working Conditions Survey 1977. Työvoimatilasto. Tilastotiedotus 1978:24. Helsinki 1978.

CSO 1979 [1] Central Statistical Office of Finland. Labour Force Survey (Postal). Official Statistics of Finland XL: 3. Helsinki 1979.

CSO 1979 [2] Central Statistical Office of Finland. Labour Force Study. Labour Force Survey (Interview Based). Työvoimatilasto. Tilastotiedotus 1979: 30. Helsinki 1979.

Kandolin Irja: Naisten työssäkäynti ja taloudellinen asema Pohjoismaissa. Sosiologian pro gradu-tutkielma 1978. Helsingin yliopisto.

Kivinen Kirsti-Vadén Totte: Mielenterveys. Jyväskylä 1978.

Niemi Iiris-Suominen Leena: Suomalainen lapsiperhe. Perheneuvosto. Helsinki 1976.

Nummenmaa Anna-Raija: Perheen työaikarakenne ja lapsen kehitysehdot. Reports from the Department of Psychology. University of Tampere 111/1978.

SOU 1975: 37 Statens offentliga utredningar. Barn och föräldrars arbete. Stockholm 1975.

SOU 1975: 62 Förkortad arbetstid för småbarnsföräldrar. Stockholm 1975.

Syvänen Matti: Työ, asuminen, vapaa-aika, perhe-elämä. Perhe ja elämäntaso. Jyväskylän Kesän -76 perhekongressin aineistoa. Perheneuvosto. Helsinki 1976.

Työvoimakatsaus 1978: 4. Työvoimaministeriö, suunnitteluosasto. Helsinki 1979. 